University of Nebraska - Lincoln

DigitalCommons@University of Nebraska - Lincoln

Spring 2005

\title{
Use of Tracers and Isotopes to Evaluate Vulnerability of Water in Domestic Wells to Septic Waste
}

Ingrid M. Verstraeten

USGS, Reston,VA, imverstr@usgs.gov

Gregory S. Fetterman

U.S. Citizenship and Immigration Service, two4cy@aol.com

Michael T. Meyer

USGS, Kansas Water Science Center, mmeyer@usgs.gov

Thomas D. Bullen

USGS, Menlo Park, CA, tdbullen@usgs.gov

Sonja Sebree

USGS Water Resources Discipline, Lincoln, NE, sksebree@usgs.gov

Follow this and additional works at: https://digitalcommons.unl.edu/usgsstaffpub

Part of the Geology Commons, Oceanography and Atmospheric Sciences and Meteorology Commons, Other Earth Sciences Commons, and the Other Environmental Sciences Commons

Verstraeten, Ingrid M.; Fetterman, Gregory S.; Meyer, Michael T.; Bullen, Thomas D.; and Sebree, Sonja, "Use of Tracers and Isotopes to Evaluate Vulnerability of Water in Domestic Wells to Septic Waste" (2005). USGS Staff -- Published Research. 1215.

https://digitalcommons.unl.edu/usgsstaffpub/1215

This Article is brought to you for free and open access by the US Geological Survey at DigitalCommons@University of Nebraska - Lincoln. It has been accepted for inclusion in USGS Staff -- Published Research by an authorized administrator of DigitalCommons@University of Nebraska - Lincoln. 


\title{
Use of Tracers and Isotopes to Evaluate Vulnerability of Water in Domestic Wells to Septic Waste
}

\author{
by I.M. Verstraeten, G.S. Fetterman, M.T. Meyer, T. Bullen, and S.K. Sebree
}

\begin{abstract}
In Nebraska, a large number ( $>200)$ of shallow sand-point and cased wells completed in coarse alluvial sediments along rivers and lakes still are used to obtain drinking water for human consumption, even though construction of sand-point wells for consumptive uses has been banned since 1987. The quality of water from shallow domestic wells potentially vulnerable to seepage from septic systems was evaluated by analyzing for the presence of tracers and multiple isotopes. Samples were collected from 26 sand-point and perforated, cased domestic wells and were analyzed for bacteria, coliphages, nitrogen species, nitrogen and boron isotopes, dissolved organic carbon (DOC), prescription and nonprescription drugs, or organic waste water contaminants. At least 13 of the 26 domestic well samples showed some evidence of septic system effects based on the results of several tracers including DOC, coliphages, $\left.\mathrm{NH}_{4}{ }^{+}, \mathrm{NO}_{3}{ }^{-}, \mathrm{N}_{2}, \delta^{15} \mathrm{~N}_{\mathrm{NO}_{3}}{ }^{-}\right]$and boron isotopes, and antibiotics and other drugs. Sand-point wells within $30 \mathrm{~m}$ of a septic system and $<14 \mathrm{~m}$ deep in a shallow, thin aquifer had the most tracers detected and the highest values, indicating the greatest vulnerability to contamination from septic waste.
\end{abstract}

\section{Introduction}

More than 100 million people in the United States use ground water as their source of drinking water (Tuthill et al. 1998), and about one-third of rural households including waterfront population $(25-30 \%$ of the households) use septic systems for waste water disposal (McAvoy et al. 1994; Robertson et al. 1991; U.S. EPA 2000). An estimated trillion liters of sewage from septic systems is released to the subsurface annually (Scandura and Sobsey 1997). This sewage can be a health risk because contaminants from sepic systems may enter the ground water that is used as a drinking water source. Disease outbreaks have been associated with ground water (Moore et al. 1994) contaminated with septic waste and viruses (Scandura and Sobsey 1997). With the increase in urban sprawl, which leads to greater septic system use and high costs of centralized waste water treatment, the problem could intensify in the future (Nizeyimana et al. 1996).

Septic tanks serve primarily as settling chambers, removing solids from the sewage. Contaminants of concern include microorganisms, nutrients, metals, and inorganic and organic chemicals, including endocrine-disrupting compounds such as pharmaceuticals (Roefer et al. 2000; Shore et al. 1993; Kolpin et al. 2002; Verstraeten et al. 2003). Contaminants seeping from septic systems can enter the

Copyright (C) 2005 National Ground Water Association No claim to original US government works. ground water especially when the water table is shallow and the unsaturated and saturated zones consist mainly of sand and gravel (Robertson et al. 1991; Scandura and Sobsey 1997). Aquifers with these characteristics also typically have high porosity and high hydraulic conductivity, resulting in large infiltration rates and low dispersion in the horizontal plane that may potentially contribute to concentrated plumes from septic systems (Wilhelm et al. 1996) in the shallow part of the aquifer. In addition, if shallow wells are in a flood-prone alluvial setting, contaminants from septic fields and surface water can be transported into the wells with floodwater. Robertson et al. (1991) suggested that current minimum distance-to-well regulations for septic system permits would not adequately protect well water quality in unconfined sandy aquifers with large longitudinal dispersivity. Mobile contaminants such as nitrates, which are sometimes not attenuated by chemical and microbiological processes, are of greatest concern. The potential presence of toxic mobile and persistent compounds in septic systems such as volatile organic compounds and pharmaceuticals from septic systems presents additional concerns (Robertson et al. 1991; Verstraeten et al. 2003). Lowe and Wallace (1999) used a mass-balance approach for nitrogen and determined that lot sizes with adequate minimum septic-to-well distances could vary from as small as 3 acres (clayey and silty aquifer) to as much as 53 acres (sandy aquifer) depending on the aquifer.

In Nebraska, a large number ( $>200)$ of shallow sandpoint and cased wells completed in coarse alluvial sediments 
along rivers and lakes still are used to obtain drinking water for human consumption, even though construction of sandpoint wells for consumptive uses has been banned since 1987 (Title 178 Department of Health and Human Services Regulation and Licensure Chapter 12, Section 004.01). Nebraska regulations since 1977 (Nebraska Department of Environmental Control 1977) also require a minimum setback distance from domestic wells of $15 \mathrm{~m}$ for septic tanks and $31 \mathrm{~m}$ for absorption fields. At times water from shallow domestic wells within $5 \mathrm{~m}$ of septic systems is used for drinking water. Gosselin et al. (1997) evaluated the presence of nitrates, pesticides, and coliform bacteria in domestic wells in Nebraska. The study indicated that nitrate concentrations (as nitrogen) in water from domestic wells exceeded $10 \mathrm{mg} / \mathrm{L}$, the U.S. EPA maximum contaminant level (MCL), in $39 \%$ of the samples. Coliform bacteria were detected in $26 \%$ of the samples.

Barrett et al. (1999) identified the need for using multiple tracers to identify contamination by septic waste and its effects on drinking water. Indicators of septic waste impacts include bacteria; coliphages; other viruses; $\mathrm{pH}$; dissolved organic carbon (DOC) $\left(\mathrm{CH}_{2} \mathrm{O}\right)$; ammonium $\left(\mathrm{NH}_{4}{ }^{+}\right)$; organic nitrogen; nitrate as nitrogen $\left(\mathrm{NO}_{3}{ }^{-}\right)$; isotopes of oxygen $\left(\delta^{18} \mathrm{O}\right)$, carbon $\left(\delta^{13} \mathrm{C}\right)$, nitrogen $\left(\delta^{15} \mathrm{~N}\right)$, and sulfur $\left(\delta^{34} \mathrm{~S}\right)$; phosphate $\left(\mathrm{PO}_{4}{ }^{3-}\right)$; chloride $(\mathrm{Cl})$; boron (B); boron isotopes $\left(\delta^{10} \mathrm{~B}\right.$ and $\left.\delta^{11} \mathrm{~B}\right)$; and household chemicals and antibiotics (Aravena and Robertson 1998; Barth 1998; Curry 1999; Francy et al. 2000; Grischek et al. 1994; Harman et al. 1996; Montana HeadWaters Inc. 1998, 1999; Robertson and Blowes 1995; Seiler et al. 1999; Tuthill et al. 1998; Vengosh et al. 1994).

This paper presents the results of a study conducted from 2001 to 2003 by the USGS in cooperation with the Lower Platte River Corridor Alliance with support from the Lower Platte South, Lower Platte North, and PapioMissouri River Natural Resources Districts (NRDs). The hypotheses were that (1) bacteria and nitrate concentrations are conservative tracers that can indicate contamination of drinking water obtained from domestic wells and (2) multiple tracers are required to assess whether water from domestic wells is impacted by septic systems. The quality of drinking water from shallow domestic wells vulnerable to seepage from septic systems was evaluated through the use of tracers and isotopes.

\section{Setting}

The study area, defined as the 100-year floodplain plus a 1.5-km buffer at both sides of the Platte River, is an area of $\sim 2600 \mathrm{~km}^{2}$ in eastern Nebraska from near Columbus to the Platte River's confluence with the Missouri River (Figure 1). The drainage area of the Platte River in Nebraska is 106,000 $\mathrm{km}^{2}$, with a mean annual flow of $\sim 200 \mathrm{~m}^{3} / \mathrm{s}$ at Plattsmouth (Verstraeten et al. 1999a). The river generally is a gaining river except for a small area upgradient. It becomes a losing river near the large wellfields of the cities of Lincoln and Omaha because of induced infiltration (Verstraeten et al. 1999b). The Platte River typically contains concentrations of $\mathrm{NO}_{3}{ }^{-}<2 \mathrm{mg} / \mathrm{L}$ (Verstraeten et al. 1998).

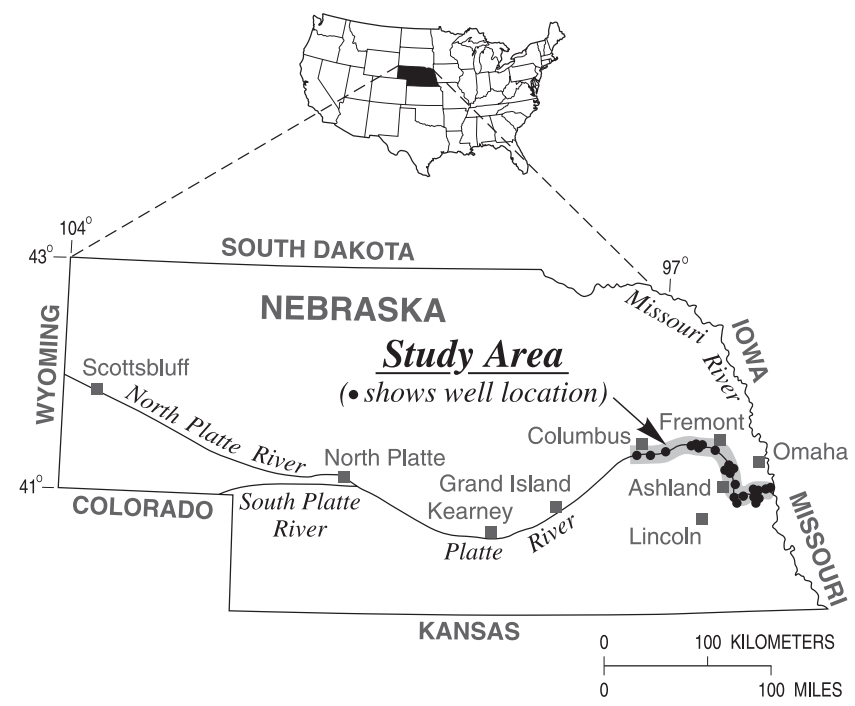

Figure 1. Study area with generalized locations of wells.

In the study area, depth to the water table generally is $<3 \mathrm{~m}$. Wells generally are completed at depths of $<30 \mathrm{~m}$ in alluvial material consisting of sand and gravel that contains some silt and clay. Occasionally, during spring melt and after heavy spring rainfall, flooding occurs along the river. The surface water sometimes contains elevated concentrations of nutrients and pesticides, especially during spring runoff events (Verstraeten et al. 1999b). Ground water at times contains concentrations of $\mathrm{NO}_{3}{ }^{-}$in excess of $10 \mathrm{mg} / \mathrm{L}$ and detectable concentrations of herbicides in some parts of the study area (Verstraeten et al. 1999b).

About $53 \%$ of the residents of the study area have domestic wells (Burns and McDonnell Inc. 1999). Thirtyfour percent of the wells in eight counties in the study area are sand-point wells, and $61 \%$ of the households have their own septic systems (Burns and McDonnell Inc. 1999; Leslie Associates Inc. 1998). In many instances, the septic systems and domestic wells were constructed before the setback distances became subject to regulation. Domestic wells are in developments at sandpit lakes, small towns where all residences have their own water supply, or at farmsteads near cornfields or small ( $<50$ cattle), unconfined animal-feeding operations. Population in the counties in the study area is projected to increase by $10 \%$ to as much as $18.4 \%$ within 10 years (Bureau of Business Research 1999).

\section{Methods}

All the wells sampled were domestic wells currently or formerly used for drinking water supply. Samples were collected from seven shallow sand-point wells for a preliminary assessment. An additional 19 well sites were selected in the study area that met the following criteria: (1) sandpoint or cased wells; (2) wells completed in the Platte River alluvium; (3) wells <30 m deep; and (4) wells within $80 \mathrm{~m}$ of a septic tank. Samples were collected from May to October 2001. The well locations were representative of the geologic (completed in a shallow, unconfined alluvial aquifer consisting mainly of sand and silt) and the 
anthropogenic (surrounded by cornfields, surrounding sandpit lakes, or on the banks of the Platte River) conditions in the study area. Five of the 26 wells were resampled 3 months after initial sample collection because of low dissolved oxygen (D.O.) concentrations, detection of coliphages, or relatively high ammonium or $\mathrm{NO}_{3}{ }^{-}$concentrations. Samples were collected from domestic wells before drinking water treatment (e.g., filtration, ion exchange, chlorination) but after (1) the water tank, if present, was emptied; (2) at least three well volumes of water were removed; and (3) field measurements had stabilized within acceptable levels: specific conductance within 5\%, $\mathrm{pH}$ within 0.1 standard unit, D.O. $0.05 \mathrm{mg} / \mathrm{L}$, and water temperature within $0.2^{\circ} \mathrm{C}$.

Samples collected from the initial seven wells were analyzed for total coliform bacteria, $\mathrm{NO}_{3}{ }^{-}$reported as $\mathrm{N}$, 60 prescription and nonprescription drugs, and 67 human (waste water related) compounds. Samples collected from the additional 19 wells were analyzed for fecal coliform bacteria, Escherichia coli, male-specific and somatic coliphages, DOC, $\mathrm{NO}_{3}{ }^{-}$and other nutrients including ammonia, and 26 antibiotics and 60 other prescription and nonprescription drugs in response to the results obtained from the first seven wells (Table 1). A subset of 5 of the 26 samples-four samples containing concentrations of $\mathrm{NO}_{3}{ }^{-}$ exceeding $10 \mathrm{mg} / \mathrm{L}$ and one sample with a low D.O. concentration $(0.13 \mathrm{mg} / \mathrm{L})$ and a $\mathrm{NO}_{3}{ }^{-}$concentration less than the detection level of $0.05 \mathrm{mg} / \mathrm{L}$ - were analyzed for dissolved gases (four samples), other nutrients (five samples), nitrogen isotopes (five samples), boron (five samples), or boron isotopes (five samples) to confirm with additional tracers whether the drinking water has been affected by septic waste and to evaluate whether denitrification might be occurring (Table 1). Two field duplicates and two equipment blanks also were collected. Results of analysis of quality-assurance samples indicated that no contamination occurred during sample collection, and reproducible results (within 5\%) were obtained. However, in one duplicate sample obtained from a sand-point well, two nonprescription drugs, ibuprofen and caffeine, were not confirmed.

\section{Results and Discussion}

Data from analyses of microorganisms, inorganic constituents, organic carbon, nitrogen and boron isotopes, and organic compounds such as antibiotics and other prescription and nonprescription drugs were evaluated for use as indicators of vulnerability to septic waste. Data from the 67 waste water-related compounds were inconclusive as indicators because of low concentrations. The evaluation presented herein relates to the geologic and the anthropogenic conditions for the alluvial aquifer adjacent to the

\begin{tabular}{|c|c|c|c|c|}
\hline \multicolumn{5}{|c|}{$\begin{array}{l}\text { Table } 1 \\
\text { Analytical Methods and Sample Size }\end{array}$} \\
\hline Analytes & Laboratory & $\begin{array}{l}\text { Reporting } \\
\text { Limit }\end{array}$ & $\begin{array}{l}\text { Number } \\
\text { of Samples }\end{array}$ & Reference \\
\hline \multicolumn{5}{|l|}{ Microorganisms } \\
\hline Total coliform bacteria $(100 \mathrm{~mL})$ & $\mathrm{NDOH}$ & Absence/presence & 7 & $\begin{array}{l}\text { Brenner et al. 1993; } \\
\quad \text { Clesceri et al. } 1998\end{array}$ \\
\hline E. coli bacteria $(100 \mathrm{~mL})$ & $\mathrm{NDOH}$ & Absence/presence & 7 & $\begin{array}{l}\text { Brenner et al. 1993; } \\
\quad \text { Clesceri et al. } 1998\end{array}$ \\
\hline Fecal coliform bacteria $(100 \mathrm{~mL})$ & $\mathrm{NDOH}$ & Enumeration & 19 & Clesceri et al. 1998 \\
\hline $\begin{array}{l}\text { Somatic and male-specific coliphages; U.S. } \\
\text { EPA methods } 1601 \text { and } 1602(1 \mathrm{~L})\end{array}$ & $\begin{array}{l}\text { Analytical } \\
\text { Services Inc. }\end{array}$ & Absence/presence & 21 & U.S. EPA2001 \\
\hline \multicolumn{5}{|l|}{$\begin{array}{l}\text { Inorganic constituents, organic } \\
\text { carbon, and isotopes }\end{array}$} \\
\hline DOC & USGS NWQL & $0.2 \mathrm{mg} / \mathrm{L}$ & 19 & Fishman and Friedman 1989 \\
\hline Nitrate & USGS NWQL & $0.05 \mathrm{mg} / \mathrm{L}$ & 26 & Fishman and Friedman 1989 \\
\hline Other nutrients including ammonia & USGS NWQL & $0.006-0.05 \mathrm{mg} / \mathrm{L}$ & 19 & Fishman and Friedman 1989 \\
\hline Dissolved gases & $\begin{array}{l}\text { USGS Dissolved } \\
\text { Gas Laboratory }\end{array}$ & $0.005-0.005 \mathrm{mg} / \mathrm{L}$ & 4 & $\begin{array}{l}\text { http://water.usgs.gov/lab/ } \\
\text { dissolved-gas }\end{array}$ \\
\hline $\mathrm{N}$ isotopes of nitrate & $\begin{array}{l}\text { USGS N isotope } \\
\text { Laboratory }\end{array}$ & $0.1 \delta^{15} \mathrm{~N}_{-} \mathrm{NO}_{3}^{-}$ & 5 & $\begin{array}{l}\text { Böhlke and Denver 1995; } \\
\text { Böhlke and Coplen } 1995\end{array}$ \\
\hline Boron & USGS Menlo Park & $1 \mu \mathrm{g} / \mathrm{L}$ & 5 & Fishman and Friedman 1989 \\
\hline Boron isotopes & USGS Menlo Park & $0.2 \%$ & 5 & Vengosh et al. 1994 \\
\hline \multicolumn{5}{|l|}{ Organic compounds } \\
\hline Selected antibiotics & $\begin{array}{l}\text { USGS Lawrence, } \\
\text { Kansas }\end{array}$ & $0.01-2.0 \mu \mathrm{g} / \mathrm{L}$ & 26 & Kolpin et al. 2002 \\
\hline $\begin{array}{l}\text { Selected prescription and } \\
\text { nonprescription drugs }\end{array}$ & USGS NWQL & $0.03-0.15 \mu \mathrm{g} / \mathrm{L}$ & 24 & Kolpin et al. 2002 \\
\hline $\begin{array}{l}\text { Human (waste water-related } \\
\text { compounds) indicators }\end{array}$ & USGS NWQL & $0.05-5.0 \mu \mathrm{g} / \mathrm{L}$ & 7 & Zaugg et al. 2002 \\
\hline
\end{tabular}


Platte River in eastern Nebraska, and the successful use of the tracers and isotopes will be dependent upon the local conditions.

\section{Microorganisms}

Total coliform bacteria, fecal coliform bacteria, E. coli, and coliphages can be indicators of septic waste contamination of drinking water. In this study, bacteria were not detected in any of the domestic well samples, indicating that there may have been sufficient residence time to allow for die-off, as was observed by Whitehead and Geary (2000). Indicator viruses (male-specific coliphages) were detected in 2 of the 19 ground water samples from sand-point wells drilled within $25 \mathrm{~m}$ of a septic field, with depths of 8 and $12 \mathrm{~m}$.

Bacterial adsorption in the subsurface may have occurred because of the presence of cations, particularly iron, ammonium from crop fertilization or septic waste (Gerba and Bitton 1984), or clogging. E. coli is considered to be an indicator of fecal contamination (U.S. EPA 2000; Shadford et al. 1997). Somatic and F-specific coliphages have been used as indicators of survival and transport of viruses (Deborde et al. 1998; Francy et al. 2000). Total coliform bacteria also appeared to be a good indicator for septic contamination, according to Francy et al. (2000). Scandura and Sobsey (1997) showed that, in sandy aquifers with a shallow water table and $\mathrm{pH}>7$, ground water can be contaminated with viruses from septic systems especially during the winter months. In the current study, the aquifer is sandy, the $\mathrm{pH}$ is generally $>7$, and viruses were detected more frequently than bacteria. The detection of malespecific coliphages suggests the presence of fecal contamination in water from at least 2 of the 21 domestic wells and potentially short transport times from the drainage field to the screens of the wells. Whether the contamination derives from the surface water body nearby, surface applications of manure, domestic septic waste, or a combination of sources remains unresolved on the basis of evidence from microorganisms. Detection of male-specific coliphages may indicate that these viruses can be transported in the aquifer's media because of their small size and negative charge.

\section{Inorganic Constituents, Organic Carbon, and Isotopes}

Nitrogen species and their isotopes, organic carbon, dissolved gases, and boron and its isotopes can be used to identify whether septic waste has affected the source of drinking water and whether denitrification plays a role in the presence of low $\mathrm{NO}_{3}{ }^{-}$concentrations. Nitrogen species cannot be considered as conservative tracers because they are actively mediated biologically through nitrification and denitrification reactions during infiltration and movement within the aquifer (Leenhouts et al. 1998). Nevertheless, $\mathrm{NH}_{4}{ }^{+}$can sometimes be a distinctive indicator of sewage. However, other sources such as fertilizer and animal wastes also could contribute to $\mathrm{NH}_{4}{ }^{+}$concentrations.

Water from 4 of the 26 wells exceeded the EPA MCL of $10 \mathrm{mg} / \mathrm{L}$ of $\mathrm{NO}_{3}{ }^{-}$as $\mathrm{N}$ (U.S. EPA 2000). $\mathrm{NO}_{3}{ }^{-}$as $\mathrm{N}$ concentrations ranged from $<0.05$ to $38.7 \mathrm{mg} / \mathrm{L}$ (Table 2). $\mathrm{NH}_{4}{ }^{+}$as $\mathrm{N}$ concentrations ranged from $<0.04$ to $1.39 \mathrm{mg} / \mathrm{L}$ (Table 2).
The presence of $\mathrm{NH}_{4}{ }^{+}$appears to be dependent upon well construction type, well depth, and distance to septic field (Figure 2). Sand-point wells of $<8 \mathrm{~m}$ deep and at a distance of $<15 \mathrm{~m}$ from the septic field appeared to contain relatively larger concentrations of $\mathrm{NH}_{4}{ }^{+}$than cased wells of $>8 \mathrm{~m}$ deep and at a distance of $>30 \mathrm{~m}$ from a septic field. Similarly, DOC concentrations appear to be greater in sand-point wells and wells at a distance of $<15 \mathrm{~m}$ from the septic field than in other wells. Wells closest to septic fields had greater concentrations of $\mathrm{NH}_{4}{ }^{+}$and DOC (Figure 3) than those farther away. In general, $\mathrm{NH}_{4}{ }^{+}$and DOC decreased with distance from the septic field. Under aerobic conditions (Equation 1), $\mathrm{NH}_{4}{ }^{+}$is oxidized easily to $\mathrm{NO}_{3}{ }^{-}$within a few hours to a few days and within distances of a few tens of centimeters (Barrett et al. 1999; Leenhouts et al. 1998; Robertson and Blowes 1995; Wilhelm et al. 1994).

$$
\mathrm{NH}_{4}^{-}+2 \mathrm{O}_{2} \rightarrow \mathrm{NO}_{3}^{-}+2 \mathrm{H}^{+}+\mathrm{H}_{2} \mathrm{O}
$$

Similarly, organic carbon will be transformed in an aerobic setting (Equation 2).

$$
\mathrm{CH}_{2} \mathrm{O}+\mathrm{O}_{2} \rightarrow \mathrm{CO}_{2}+\mathrm{H}_{2} \mathrm{O} \leftrightarrow \mathrm{H}_{2} \mathrm{CO}_{3} \leftrightarrow \mathrm{H}^{+}+\mathrm{HCO}_{3}^{-}
$$

Equations 1 and 2 illustrate reactions that decrease the $\mathrm{pH}$ of ground water (Robertson and Blowes 1995), which may be reflected in association with low $\mathrm{pH}$ and high $\mathrm{NO}_{3}{ }^{-}$in samples collected from wells between 16 and 29 $\mathrm{m}$ away from septic drainage fields.

In cases where vadose zone residence time is relatively short (hours or $<1$ week), the oxidation process may remain incomplete. Short residence times may result in greater $\mathrm{NH}_{4}{ }^{+}$, lower $\mathrm{NO}_{3}{ }^{-}$, greater DOC (above background concentrations from other sources), and lower D.O. concentrations than when residency in the unsaturated zone is relatively long ( $>7$ days) (Robertson et al. 1991). Short residence times may occur at some locations (such as short distances between septic field and domestic well and a shallow water table) sampled during this project. Under anaerobic conditions, denitrification can occur and $\mathrm{NO}_{3}{ }^{-}$is transformed to $\mathrm{N}_{2}$ gas (Equation 3).

$$
5 \mathrm{CH}_{2} \mathrm{O}+4 \mathrm{NO}_{3}^{-}+4 \mathrm{H}^{+} \rightarrow 2 \mathrm{~N}_{2}+5 \mathrm{CO}_{2}+7 \mathrm{H}_{2} \mathrm{O}
$$

Anaerobic conditions can develop if substantial amounts of labile organic carbon, possibly derived from septic waste, are present in the aquifer media. Wilhelm et al. (1996) reported that denitrification occurred over distances $<2 \mathrm{~m}$ and decreased $\mathrm{NO}_{3}{ }^{-}$concentrations from 40 to $<0.05 \mathrm{mg} / \mathrm{L}$ near a river in Ontario, Canada.

Analyses of dissolved gases from four domestic wells in the study area confirmed that denitrification could be a process in the local aquifer causing $\mathrm{NO}_{3}{ }^{-}$to be depleted and $\mathrm{N}_{2}$ gas to be produced. For example, water from a 12-m-deep sand-point well located $21 \mathrm{~m}$ from a septic field appeared completely denitrified, with $<0.05 \mathrm{mg} / \mathrm{L} \mathrm{NO}_{3}{ }^{-}$, $0.13 \mathrm{mg} / \mathrm{L}$ D.O., $11.7 \mathrm{mg} / \mathrm{L} \mathrm{N} \mathrm{N}_{2}$ gas in excess of values in equilibration with the atmosphere, and $1.4 \mathrm{mg} / \mathrm{L} \mathrm{CH}$. Other ground water (two wells completed at $<10$-m depth 
Table 2

Statistics for Selected Constituents

\begin{tabular}{|c|c|c|c|c|c|c|}
\hline Constituent & $\begin{array}{c}\text { Method } \\
\text { Reporting Level }\end{array}$ & $\begin{array}{c}\text { Number } \\
\text { of Samples }\end{array}$ & Minimum & Mean & Median & Maximum \\
\hline \multicolumn{7}{|l|}{ All wells } \\
\hline Well depth (m) & $-^{a}$ & 26 & 5.0 & 10 & 8.5 & 30 \\
\hline $\begin{array}{l}\text { Distance of well to laterals } \\
\text { of septic field (m) }\end{array}$ & $-^{\mathrm{a}}$ & 26 & 8.0 & 26 & 20 & 76 \\
\hline D.O. & 0.05 & 25 & 0.06 & 1.12 & 0.17 & 12.0 \\
\hline pH (standard units) & 0.10 & 26 & 6.3 & 7.2 & 7.2 & 7.8 \\
\hline $\begin{array}{l}\text { Specific conductance } \\
\left(\mu \mathrm{S} / \mathrm{cm} \text { at } 25^{\circ} \mathrm{C}\right)\end{array}$ & & 26 & 285 & 548 & 572 & 709 \\
\hline DOC & 0.20 & 14 & 0.5 & 2.8 & 3.1 & 4.3 \\
\hline Ammonia as nitrogen $(\mathrm{mg} / \mathrm{L})$ & 0.04 & 19 & $<0.04$ & 0.40 & 0.17 & 1.39 \\
\hline Nitrate as nitrogen $(\mathrm{mg} / \mathrm{L})$ & 0.05 & 26 & $<0.05$ & 4.39 & $<0.05$ & 38.7 \\
\hline Nitrite as nitrogen $(\mathrm{mg} / \mathrm{L})$ & 0.006 & 19 & $<0.006$ & 0.004 & $<0.006$ & 0.09 \\
\hline Boron $(\mu \mathrm{g} / \mathrm{L})$ & 0.02 & 5 & 38 & $-^{\mathrm{a}}$ & $-^{\mathrm{a}}$ & 193 \\
\hline Boron isotopes (\%) & 0.2 & 5 & -0.2 & $\ldots^{\mathrm{a}}$ & ${ }^{\mathrm{a}}$ & +14.5 \\
\hline \multicolumn{7}{|l|}{ Statistics by well type } \\
\hline \multicolumn{7}{|l|}{ Cased wells } \\
\hline Organic carbon & 0.2 & 8 & 0.8 & 2.6 & 2.6 & 4.2 \\
\hline Nitrate $\left(\mathrm{NO}_{3}{ }^{-}\right)$ & 0.05 & 12 & $<0.05$ & 4.77 & $<0.05$ & 38.7 \\
\hline Ammonia $\left(\mathrm{NH}_{4}^{+}\right)$ & 0.04 & 10 & $<0.04$ & 0.22 & 0.04 & 0.93 \\
\hline \multicolumn{7}{|l|}{ Sand-point wells } \\
\hline Organic carbon & 0.2 & 6 & 0.54 & 3.1 & 3.4 & 4.3 \\
\hline Nitrate & 0.05 & 14 & $<0.05$ & 4.06 & $<0.05$ & 30.2 \\
\hline Ammonia & 0.04 & 10 & $<0.04$ & 0.60 & 0.43 & 1.39 \\
\hline \multicolumn{7}{|l|}{ Statistics by well depth } \\
\hline \multicolumn{7}{|l|}{$<8 \mathrm{~m}$} \\
\hline Organic carbon & 0.2 & 3 & 2.4 & 3.0 & 3.1 & 3.6 \\
\hline Nitrate & 0.05 & 7 & $<0.05$ & 2.42 & $<0.05$ & 17.0 \\
\hline Ammonia & 0.04 & 4 & 0.33 & 0.63 & 0.41 & 1.39 \\
\hline \multicolumn{7}{|l|}{$8-14 \mathrm{~m}$} \\
\hline Organic carbon & 0.2 & 8 & 0.54 & 3.2 & 3.5 & 4.3 \\
\hline Nitrate & 0.05 & 15 & $<0.05$ & 3.35 & $<0.05$ & 30.2 \\
\hline Ammonia & 0.04 & 12 & $<0.04$ & 0.41 & 0.14 & 1.23 \\
\hline \multicolumn{7}{|l|}{$\geq 15 \mathrm{~m}$} \\
\hline Organic carbon & 0.2 & 3 & 0.77 & 1.7 & 1.7 & 2.7 \\
\hline Nitrate & 0.05 & 4 & $<0.05$ & 11.7 & 4.12 & 38.7 \\
\hline Ammonia & 0.04 & 3 & $<0.04$ & NA & $<0.04$ & 0.07 \\
\hline \multicolumn{7}{|l|}{$\begin{array}{l}\text { Statistics by distance of well } \\
\text { to laterals of septic field } \\
\leqslant 15 \mathrm{~m}\end{array}$} \\
\hline Organic carbon & 0.2 & 5 & 3.1 & 3.7 & 3.6 & 4.3 \\
\hline Nitrate & 0.05 & 9 & $<0.05$ & 0.02 & $<0.05$ & 0.09 \\
\hline Ammonia & 0.04 & 6 & 0.17 & 0.71 & 0.58 & 1.39 \\
\hline \multicolumn{7}{|l|}{$16-29 \mathrm{~m}$} \\
\hline Organic carbon & 0.2 & 3 & 0.5 & 2.2 & 2.4 & 3.8 \\
\hline Nitrate & 0.05 & 6 & $<0.05$ & 10.4 & 7.51 & 30.2 \\
\hline Ammonia & 0.04 & 4 & $<0.04$ & 0.24 & 0.16 & 0.63 \\
\hline \multicolumn{7}{|l|}{$\geq 30 \mathrm{~m}$} \\
\hline Organic carbon & 0.2 & 6 & 0.77 & 2.4 & 2.4 & 4.0 \\
\hline Nitrate & 0.05 & 11 & $<0.05$ & 4.71 & $<0.05$ & 38.7 \\
\hline Ammonia & 0.04 & 9 & $<0.04$ & 0.26 & $<0.04$ & 1.23 \\
\hline
\end{tabular}

at a distance of $<13 \mathrm{~m}$ from a septic waste field) appeared suboxic, with $<1.0 \mathrm{mg} / \mathrm{L}$ D.O., $\mathrm{NO}_{3}{ }^{-}$and $\mathrm{N}_{2}$ gas present, and methane absent. The generally low $(<1.00 \mathrm{mg} / \mathrm{L})$ concentrations of D.O. in water from 20 of the 26 domestic wells (Table 2) indicate reduced conditions that may permit denitrification; therefore, denitrification may be affecting $\mathrm{NO}_{3}{ }^{-}$in water from the zone of influence of the domestic wells. Temporal changes in the biogeochemistry 

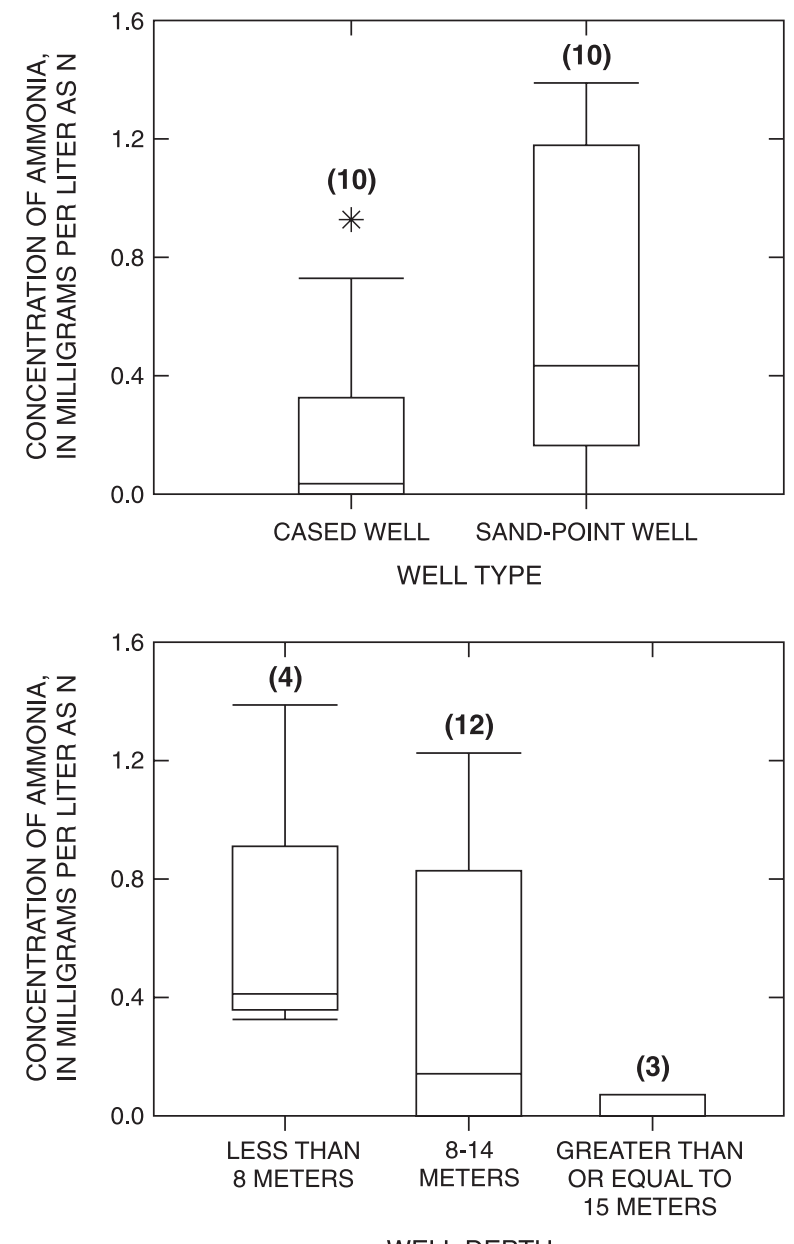

WELL DEPTH

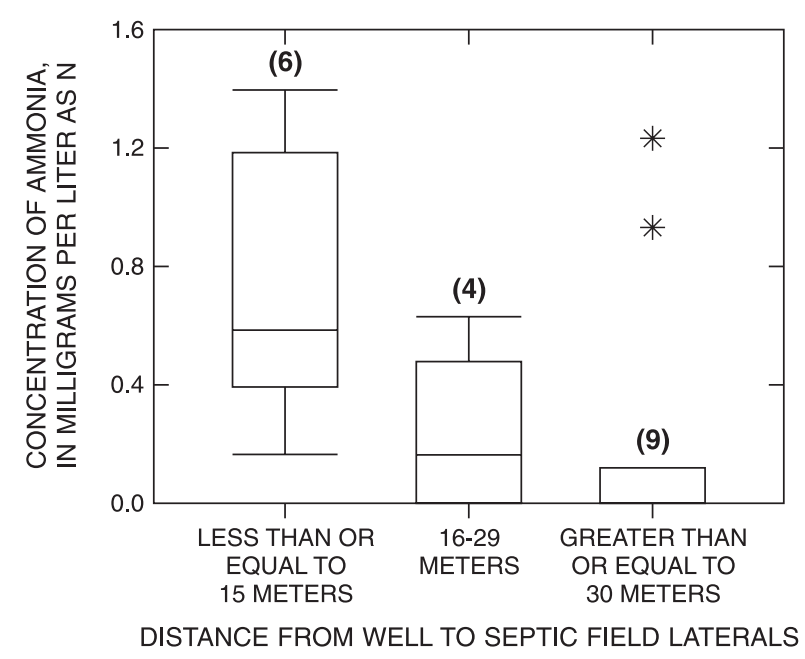

\section{EXPLANATION}

(10) Number of observations

* Outlier data value less than or equal to 3 times and greater than 1.5 times the interquartile range outside the quartile

Data value less than or equal to 1.5 times
the interquartile range outside the quartile
75th percentile
Median
25th percentile

Figure 2. Ammonia by well construction type, well depth, and distance from septic field laterals.

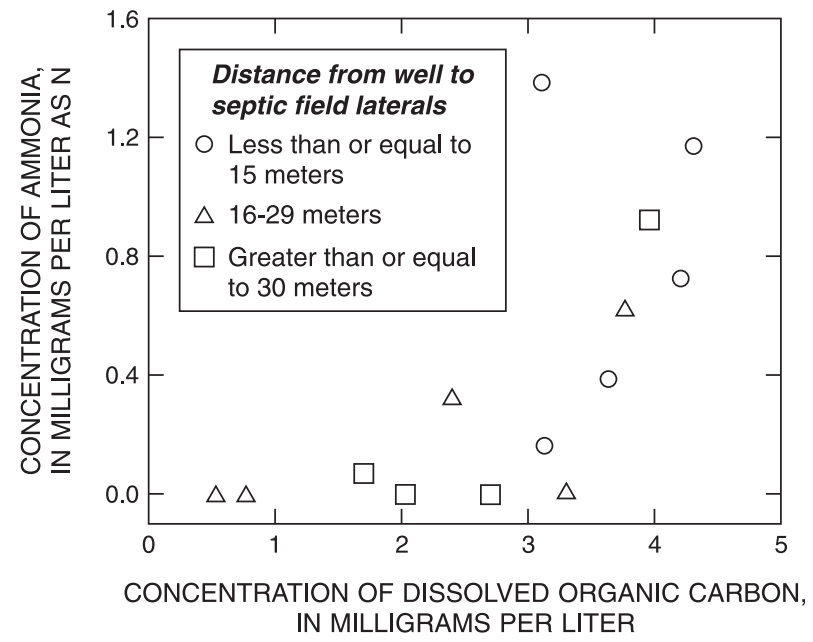

Figure 3. Relation of ammonia and DOC.

of the aquifer were indicated in water from a cased well $23 \mathrm{~m}$ deep and $46 \mathrm{~m}$ from a septic field because nitrate concentrations varied from $39 \mathrm{mg} / \mathrm{L}$ collected in September 2001 to $0.08 \mathrm{mg} / \mathrm{L}$ collected in December 2001.

Nitrogen isotopes tend to be less conservative than boron isotopes in the study area because nitrogen generally will be in its reduced $\mathrm{NH}_{4}{ }^{+}$form when released from a septic system —other sources of $\mathrm{NH}_{4}{ }^{+}$are thought to be insignificant based on field observations and interviews with well or land owners. Given the right conditions, $\mathrm{NH}_{4}{ }^{+}$ easily changes to $\mathrm{NH}_{3}$, which volatilizes and causes a preferential loss of the lighter isotope (resulting in more positive values of $\delta^{15} \mathrm{~N}$ of $\mathrm{NH}_{3}$ ) (Leenhouts et al. 1998). During denitrification, $\left.\delta^{15} \mathrm{~N} \mathrm{NO}_{3}{ }^{-}\right]$values increase (Aravena and Robertson 1998; Komor and Anderson 1993) as well. Nevertheless, detections of $\left.\delta^{15} \mathrm{~N}_{\mathrm{NO}_{3}}{ }^{-}\right]$in conjunction with other tracers can be used to differentiate the sources of nitrogen from soil $(0 \%$ o to $+4 \%$ o $)$ or fertilizer $(-2 \%$ to $+4 \%$ ), animals $(+8 \%$ to $+20 \%$ o $)$, and septic tanks $(+2 \%$ o to $+12 \%$ ) (Fogg et al. 1998). Fogg et al. (1998) also determined that it could be difficult to distinguish a geologic $\mathrm{N}$ $(+3 \%$ to $+9 \%$ o $)$ source from septic tank or commercial fertilizer sources using $\left.\delta^{15} \mathrm{~N}_{\mathrm{NO}_{3}}{ }^{-}\right]$. The low $\delta^{15} \mathrm{~N}\left[\mathrm{NO}_{3}{ }^{-}\right]$ value $(+3.2 \%)$ of water from one domestic well in the study area may indicate influences of fertilizer, soil, or, potentially, septic tanks. Based on the local land use (corn) and distance from the septic field $(18 \mathrm{~m})$, fertilizer use may be the primary source of nitrogen $\left(33.6 \mathrm{mg} / \mathrm{L} \mathrm{NO}_{3}{ }^{-}\right)$in samples from this well. The greater $\delta^{15} \mathrm{~N}\left[\mathrm{NO}_{3}{ }^{-}\right]$values of water from two wells $(12.26 \%$ and $7.93 \%$ ) could indicate that the water is affected by septic waste. However, these values probably were affected by denitrification because of suboxic conditions at both sites (see discussion of dissolved gases) and therefore are inconclusive in the absence of confirmation of septic contamination by other tracers. The results of the study indicate that nitrogen species did not behave conservatively as tracers of septic waste because of biogeochemical processes present in the aquifer media. It appears that (1) water collected from domestic wells $<15 \mathrm{~m}$ from a septic system had large concentrations of $\mathrm{NH}_{4}{ }^{+}$; (2) water from domestic wells $16-29 \mathrm{~m}$ from the septic system 
had lower concentrations of $\mathrm{NH}_{4}{ }^{+}$and larger concentrations of $\mathrm{NO}_{3}{ }^{-}$; and (3) water from domestic wells $>30 \mathrm{~m}$ from a septic field (or system) had low D.O., low $\mathrm{NH}_{4}{ }^{+}$, and low $\mathrm{NO}_{3}{ }^{-}$(Figure 4), potentially caused by processes such as denitrification and dilution.

On the other hand, the boron data confirm that boron concentrations and boron isotopes could be good indicators of sewage because they are major constituents of detergents (sodium perborate) (Vengosh et al. 1994) and because boron isotopes tend to be a relatively conservative tracer in a hydrogeologic setting with low clay content and neutral pH (Ford and Tellam 1994; Leenhouts et al. 1998). In the study area, the soils are sandy and have low clay content.

Boron concentrations in five water samples from the study area ranged from 38 to $193 \mu \mathrm{g} / \mathrm{L}$. Boron isotope values varied from $-0.2 \%$ to $+14.5 \%$. Typically, water affected by waste water tends to have a boron isotopic signature of $+5 \%$ or less (Vengosh et al. 1994). Nonmarine borate minerals, which are used to make the perborate additive to detergents, ranged from $\sim 0 \%$ to $+10 \%$. Boron isotope data collected in February 2002 from drinking water of the city of Lincoln showed a value of $+14 \%$. Water from the wellfield supplying Lincoln's drinking water indirectly receives water from the Platte River through induced infiltration. Two of the five ground water samples suspected to be influenced by septic waste on the basis of nitrogen concentrations, nitrogen isotopes, organic carbon concentrations, general hydrogeologic setting, and

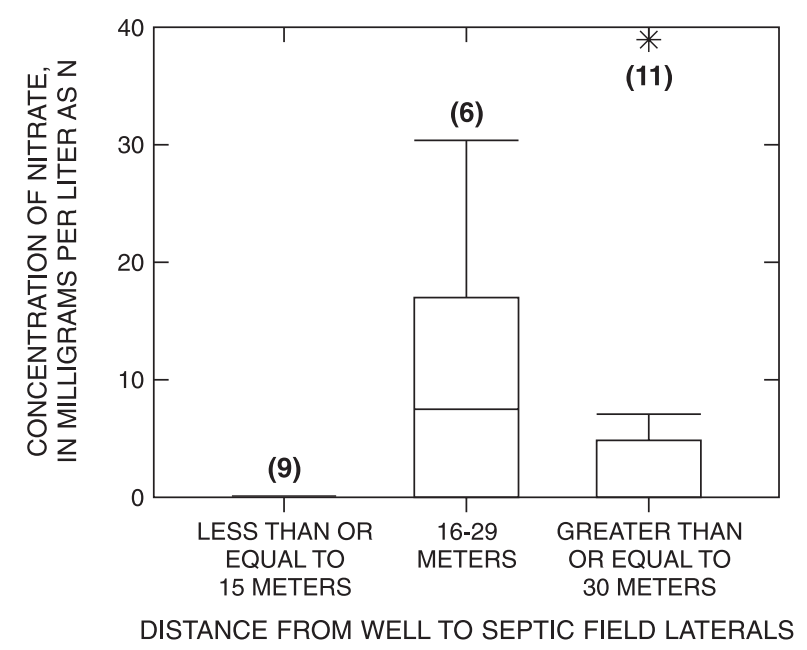

\section{EXPLANATION}

(11) Number of observations

* Outlier data value less than or equal to 3 times and greater than 1.5 times the interquartile range outside the quartile

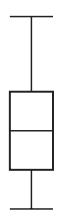

Data value less than or equal to 1.5 times the interquartile range outside the quartile

75th percentile

Median

25th percentile

Figure 4. Relation of nitrate concentrations to distance from septic field laterals. well construction had boron values of $-0.2 \%$ and $0.7 \%$, consistent with waste water effects. The other three samples containing large nitrogen concentrations or detections of coliphages are thought to be contaminated with local fertilizer applications to corn cropland, by a nearby small feedlot, barns, and roaming cattle, or with fertilizer applied to the lawn.

\section{Organic Compounds}

The samples collected from the initial seven wells were analyzed for prescription and nonprescription pharmaceuticals, antibiotics, and a variety of household and industrial organic compounds using three analytical methods described in Kolpin et al. (2002). Because none of the household and industrial compounds were detected in these samples, they were not analyzed in the subsequently collected samples.

Antibiotics were detected in water from three sandpoint wells (Table 3). These wells are in developments at sandpit lakes or small towns where all residences have their own water supply, and septic systems are far from animalfeeding operations. Trace concentrations $(0.05 \mu \mathrm{g} / \mathrm{L})$ of three fluoroquinolones-ciprofloxacin, enrofloxacin, and sarafloxacin-were detected in a sample from a sand-point well, $6 \mathrm{~m}$ deep, at a distance of $30 \mathrm{~m}$ from a septic system, with $0.17 \mathrm{mg} / \mathrm{L}$ D.O. and $<0.05 \mathrm{mg} / \mathrm{L} \mathrm{NO}_{3}{ }^{-}$. One of the seven sulfonamides $-0.15 \mu \mathrm{g} / \mathrm{L}$ sulfamethoxazole-was detected in a sample from a sand-point well, $2 \mathrm{~m}$ deep, at a distance of $18 \mathrm{~m}$ from a septic system, with $0.08 \mathrm{mg} / \mathrm{L}$ D.O. and $17 \mathrm{mg} / \mathrm{L} \mathrm{NO}_{3}{ }^{-}$. Trimethoprim and erythromycin$\mathrm{H}_{2} \mathrm{O}$, a metabolite of one of the five macrolides, were detected at concentrations of 0.58 and $0.75 \mu \mathrm{g} / \mathrm{L}$, respectively, in a sand-point well, $6 \mathrm{~m}$ deep, at a distance of $\sim 8 \mathrm{~m}$ from a septic system, with $0.11 \mathrm{mg} / \mathrm{L}$ D.O. and $<0.05 \mathrm{mg} / \mathrm{L} \mathrm{NO}_{3}^{-}$.

Caffeine and other prescription and nonprescription drugs also can be indicators of waste water contamination in water from wells (Seiler et al. 1999). Eight nonprescription or prescription drugs (Table 3) were detected in water from 12 of the 19 domestic wells at concentrations as much as $0.129 \mu \mathrm{g} / \mathrm{L}$. Although recent studies have shown that a variety of pharmaceutical compounds can be transported into our nation's water resources (e.g., Kolpin et al. 2002), whether these compounds individually or as mixtures have deleterious effects on water quality is not known. In addition, little has been published on the fate and transport of pharmaceuticals in the unsaturated and saturated zones (Drewes et al. 2003; Heberer and Verstraeten in press). Organic compounds can be biodegraded in the subsurface, especially in an aerobic medium, leading to a wide variety of degradates (Drewes et al. 2003; McAvoy et al. 1994; Robertson 1994; Vengosh et al. 1994; Verstraeten et al. 2002a, 2002b, 2003). On the other hand, anaerobic or suboxic conditions, which can exist near septic fields, could prevent or slow down the degradation of organic compounds in ground water. Organic compounds also can be adsorbed to aquifer media. Because people use differing amounts and types of pharmaceuticals, the concentrations of these products or compounds cannot be used as indicators of intensity of contamination in this study. 
Table 3

Summary of Detections and Concentrations of Selected Coliphage, Prescription, and Nonprescription Drugs Including Antibiotics, by Well Type.

\begin{tabular}{|c|c|c|c|c|c|c|c|}
\hline \multirow[b]{2}{*}{$\begin{array}{l}\text { Type of Compound/ } \\
\text { Organism }\end{array}$} & \multirow[b]{2}{*}{ Use } & \multirow{2}{*}{$\begin{array}{c}\text { Method } \\
\text { Reporting } \\
\text { Level }(\mu \mathrm{g} / \mathrm{L})\end{array}$} & \multirow{2}{*}{$\begin{array}{l}\text { Number of } \\
\text { Samples } \\
\text { Analyzed }\end{array}$} & \multirow{2}{*}{$\begin{array}{c}\text { Number } \\
\text { of Detects }\end{array}$} & \multicolumn{2}{|c|}{ Detection by Well Type (n/z) } & \multirow{2}{*}{$\begin{array}{l}\text { Maximum } \\
\text { Concentration } \\
(\mu \mathrm{g} / \mathrm{L})\end{array}$} \\
\hline & & & & & $\begin{array}{l}\text { Sand-point } \\
\text { well }\end{array}$ & $\begin{array}{c}\text { Cased } \\
\text { well }\end{array}$ & \\
\hline Coliphage & Microorganism & NA & 19 & 2 & $2 / 8$ & $0 / 11$ & NA \\
\hline Ciprofloxacin & Antibiotic & 0.020 & 24 & 1 & $1 / 14$ & $0 / 10$ & Trace \\
\hline Enrofloxacin & Antibiotic & 0.020 & 24 & 1 & $1 / 14$ & $0 / 10$ & Trace \\
\hline Sarafloxacin & Antibiotic & 0.020 & 24 & 1 & $1 / 14$ & $0 / 10$ & Trace \\
\hline Sulfamethoxazole & Antibiotic & 0.023 & 25 & 2 & $2 / 14$ & $0 / 11$ & $0.15^{\mathrm{a}}$ \\
\hline Trimethoprim & Antibiotic & 0.030 & 24 & 2 & $2 / 14$ & $0 / 10$ & 0.58 \\
\hline Erythromycin- $\mathrm{H}_{2} \mathrm{O}$ & Antibiotic metabolite & 0.050 & 22 & 1 & $1 / 13$ & $0 / 9$ & 0.75 \\
\hline Caffeine & Medical, diuretic & 0.014 & 19 & 9 & $4 / 10$ & $5 / 9$ & 0.120 \\
\hline Cotinine & Nicotine metabolite & 0.023 & 19 & 1 & $1 / 10$ & $0 / 9$ & 0.060 \\
\hline Acetaminophen & Analgesic & 0.0086 & 19 & 5 & $2 / 10$ & 3/9 & $0.015^{\mathrm{a}}$ \\
\hline 1,7-dimethylxanthine & Caffeine metabolite & 0.019 & 19 & 6 & $2 / 10$ & $4 / 9$ & 0.022 \\
\hline Codeine & $\begin{array}{l}\text { Opioid narcotic, } \\
\text { cough suppressant }\end{array}$ & $\mathrm{ND}$ & 19 & 1 & $1 / 10$ & $0 / 9$ & $0.080^{\mathrm{a}}$ \\
\hline Ibuprofen & Analgesic & 0.018 & 19 & 1 & $1 / 10$ & $0 / 9$ & 0.129 \\
\hline Dehydronifedipine & Antianginal metabolite & ND & 19 & 1 & $1 / 10$ & $0 / 9$ & $0.003^{\mathrm{a}}$ \\
\hline Warfarin & Anticoagulant & 0.0061 & 19 & 1 & $1 / 10$ & $0 / 9$ & $0.009^{\mathrm{a}}$ \\
\hline
\end{tabular}

\section{Conclusions}

Based on the results of analyses of several tracers, including DOC, coliphages, $\mathrm{NH}_{4}{ }^{+}, \mathrm{NO}_{3}{ }^{-}, \mathrm{N}_{2}$, and organic compounds, at least 13 of the 26 domestic wells showed some evidence of septic waste contamination of drinking water. The evidence of septic waste contamination was especially strong when multiple indicators of sewage contamination such as the presence of coliphages, caffeine, and pharmaceuticals were detected in a sample from the same well. Other combinations included a high $\mathrm{NO}_{3}{ }^{-}$concentration in combination with a low boron value and several pharmaceuticals in combination with a high $\mathrm{NH}_{4}{ }^{+}$ concentration. Domestic wells seemed to be more vulnerable to septic waste contamination when they were sandpoint wells within $30 \mathrm{~m}$ of a septic wellfield and were $<15 \mathrm{~m}$ deep in the shallow $(<3 \mathrm{~m})$, thin $(<30 \mathrm{~m})$ alluvial aquifer studied. The study illustrates that the presence or abundance of bacteria and $\mathrm{NO}_{3}{ }^{-}$alone is not good indicator of septic waste contamination in an anaerobic setting. Bacterial transport to ground water depends on sediment type, travel times, and clogging. Analyses for smaller organisms, such as coliphages or other indicator viruses, might be a more conservative indicator of waste contamination of ground water from animal or human sources and might be better indicators than bacteria because they are smaller, generally have a lower tendency to adsorb because of their negative charge, and tend to survive longer. The presence of $\mathrm{NO}_{3}{ }^{-}$depends on the biogeochemical conditions in the unsaturated and saturated zones. All nitrogen species should be analyzed to assess more fully whether contamination of the aquifer media with nitrogen exists.
When suboxic conditions exist, samples may need to be collected multiple times per year from domestic wells since different nitrogen forms, $\mathrm{NH}_{4}{ }^{+}, \mathrm{NO}_{3}{ }^{-}$, and/or $\mathrm{N}_{2}$, can occur. Using boron isotopes and, to a lesser extent, $\delta^{15} \mathrm{~N}\left[\mathrm{NO}_{3}{ }^{-}\right]$isotopes could help to identify the sources of contamination, according to this study and other published studies.

Organic compounds can be used to assess contamination by septic waste in domestic drinking water. However, organic compounds, similar to DOC $\left(\mathrm{CH}_{2} \mathrm{O}\right)$, can degrade during oxidation. Because D.O. generally was low $(<0.17 \mathrm{mg} / \mathrm{L})$ in the aquifer materials sampled, oxidation of organic compounds probably did not occur. The presence of pharmaceuticals suggests that they may be used as indicators of septic waste in aquifers under anaerobic conditions.

In conclusion, even though we did not detect bacteria during this study, individual tracers such as bacteria and $\mathrm{NO}_{3}{ }^{-}$at times could be good tools to identify whether drinking water is affected by septic waste. However, the use of multiple biological and chemical tracers including isotopes is more informative because it helps scientists to avoid erroneous interpretations when the local hydrology and biochemical processes affect the presence or concentrations of individual tracers such as bacteria and $\mathrm{NO}_{3}{ }^{-}$. The limited number of wells sampled in this study precluded definitive conclusions on the combinations of chemical constituents and parameters that would best serve as indicators of septic waste contamination in ground water. However, the data from this study indicate that selected combinations of tracers may be useful indicators of septic waste contamination in ground water. To more fully assess 
the usefulness of these combinations, more comprehensive studies assessing differing contaminant sources need to be conducted.

\section{Acknowledgments}

The authors thank the well owners for participating in the study and for giving permission to the USGS to sample their domestic wells. We also acknowledge collaboration from the Nebraska Department of Health, the constructive comments from many other Nebraska State and local agencies, and the contributions of JohnKarl Böhlke, Michael Doughten, Steven Zaugg, and Jeffrey Cahill of the USGS. This project was completed in cooperation with the Lower Platte South NRD, the Lower Platte North NRD, the Papio-Missouri River NRD, and the Lower Platte River Corridor Alliance.

Editor's Note: The use of brand names in peer-reviewed papers is for identification purposes only and does not constitute endorsement by the authors, their employers, or the National Ground Water Association.

\section{References}

Aravena, R., and W.D. Robertson. 1998. Use of multiple isotope tracers to evaluate denitrification in ground water: Study of nitrate from a large-flux septic system plume. Ground Water 36, no. 6: 975-982.

Barrett, M.H., K.M. Hiscock, S. Pedley, D.N. Lerner, J.H. Tellam, and M.J. French. 1999. Marker species for identifying urban groundwater recharge sources: A review and case study in Nottingham, UK. Water Research 33, no. 14: 3083-3097.

Barth, S. 1998. Application of boron isotopes for tracing sources of anthropogenic contamination in groundwater. Water Research 32, 685-690.

Böhlke, J.K., and T.B. Coplen. 1995. Interlaboratory comparison of reference materials for nitrogen-isotope-ratio measurements. In Reference and Intercomparison Materials for Stable Isotopes of Light Elements, 51-66. IAEA TECDOC 825. International Atomic Energy Agency. Vienna, Austria: International Atomic Energy Agency.

Böhlke, J.K., and J.M. Denver. 1995. Combined use of groundwater dating, chemical, and isotopic analyses to resolve the history and fate of nitrate contamination in two agricultural watersheds, Atlantic coastal plain, Maryland. Water Resources Research 31, no. 9: 2319-2339.

Brenner, K.P., C.C. Rankin, Y.R. Roybal, G.N. Stelma, Jr., P.V. Scarpino, and A.P. Dufour. 1993. New medium for the simultaneous detection of total coliforms and Escherichia coli in water. Applied and Environmental Microbiology 59, no. 11: 3534-3544.

Bureau of Business Research. 1999. Nebraska population projections 1990 to 2020. Lincoln, Nebraska: University of Nebraska-Lincoln (www.bbr.unl.edu.).

Burns and McDonnell Inc. 1999. Water quality investigation: Lower Platte River Feasibility Study, prepared for Lower Platte River Corridor Alliance, Lincoln, Nebraska and U.S. Department of the Army Corps of Engineers, Omaha District. Omaha, Nebraska.

Clesceri, L.S., A.E. Greenberg, and A.D. Eaton, eds. 1998. Standard methods for the examination of water and wastewater, 20th ed, vol. 9. Baltimore, Maryland: United Book Press Inc.
Curry, D.S. 1999. Final report for the septic siting project: New York City Department of Environmental Protection, Division of Water Quality Control, Bureau of Water Supply, Quality, and Protection. New York: Department of Environmental Protection.

Deborde, D.C., W.W. Woessner, B. Lauerman, and P. Ball. 1998. Coliphage prevalence in high school septic effluent and associated ground water. Water Research 32, no.12: 3781-3785.

Drewes, J.E., T. Heberer, T. Rauch, and K. Reddersen. 2003. Fate of pharmaceuticals during ground water recharge. Ground Water Monitoring and Remediation 23, no. 3: 64-72.

Fishman, M.J., and L.C. Friedman, eds. 1989. Methods for determination of inorganic substances in water and fluvial sediments. U.S. Geological Survey Techniques of Water-Resources Investigations, Book 5, Chapter A1.

Fogg, G.E., D.E. Rolston, D.L. Decker, D.T. Louie, and M.E. Grismer. 1998. Spatial variation in nitrogen isotope values beneath nitrate contaminated sources. Ground Water 36, no. 3 : $418-426$.

Ford, M., and J.H. Tellam. 1994. Source, type, and extent of inorganic contamination within the Birmingham urban aquifer system, UK. Journal of Hydrology 156, nos. 1-4: 101-135.

Francy, D.S., D.R. Helsel, and R.A. Nally. 2000. Occurrence and distribution of microbiological indicators in groundwater and stream water. Water Environment Research 72, no. 2: 152-161.

Gerba, C.P., and G. Bitton. 1984. Microbial pollutants-Their survival and transport pattern to groundwater. In Groundwater Pollution Microbiology, ed. G. Bitton and C.P. Gerba, 65-88. New York: John Wiley and Sons.

Gosselin, D.C., J. Headrick, R. Tremblay, X.-H. Chen, and S. Summerside. 1997. Domestic well water quality in rural Nebraska: Focus on nitrate-nitrogen, pesticides, and coliform bacteria. Ground Water Monitoring and Remediation 17, no. 2 : 77-87.

Grischek, T., W. Nestler, J. Dehnert, and P. Neitzel. 1994. Groundwater/river interaction in the Elbe river basin in Saxony. In Second International Conference on Groundwater Ecology, 309-318. U.S. Environmental Protection Agency. Middleburg, Virginia: American Water Resources Association.

Harman, J., W.D. Robertson, J.A. Cherry, and L. Zanini. 1996. Impacts on a sand aquifer from an old septic system: Nitrate and phosphate. Ground Water 34, no. 6: 1105-1114.

Heberer, T., and I.M. Verstraeten, eds. 2004. Fate and transport of endocrine disrupting compounds during ground-water recharge. Ground Water Monitoring and Remediation, Spring 2004 (compilation of papers from the 2003 NGWA EDC conference).

Kolpin, D.W., E.T. Furlong, M.T. Meyer, E.M. Thurman, S.D. Zaugg, L.B. Barber, and H.T. Buxton. 2002. Pharmaceuticals, hormones, and other organic wastewater contaminants in U.S. streams, 1999-2000: Methods, development and national reconnaissance. Environmental Science and Technology 36, no. 6: 1202-1211.

Komor, S.C., and H.W. AndersonJr. 1993. Nitrogen isotopes as indicators of nitrate sources in Minnesota sand-plain aquifers. Ground Water 31, no. 2: 260-270.

Leenhouts, J.M., R.L. Bassett, and T. Maddock III. 1998. Utilization of intrinsic boron isotopes as co-migrating tracers for identifying potential nitrate contamination sources. Ground Water 36, March: 240-250.

Leslie Associates Inc. 1998. The Lower Platte River Corridor Alliance 1998 Research Reports 6-168. Omaha, Nebraska: Leslie Associates Inc.

Lowe, M., and J. Wallace. 1999. A mass-balance approach for recommending septic-tank system density/lot size based on 
nitrate loading: Three Utah examples, Abstract with Program, A-22. Geological Society of America. Salt Lake City, Utah: Utah Department of Natural Resources.

McAvoy, D.C., C.E. White, B.L. Moore, and R.A. Rapaport. 1994. Chemical fate and transport in a domestic septic system: Sorption and transport of anionic and cationic surfactants. Environmental Toxicology and Chemistry 13, no. 2: 213-221.

Montana HeadWaters Inc. 1999. Sample collection and analytical results document for conducting male-specific coliphage sampling of septic tanks. Phase II: Missoula, Montana, SAIC Project No. 01-0833-08-3557-000. State of Montana.

Montana HeadWaters Inc. 1998. Sample collection and analytical results document for conducting male-specific coliphage sampling of septic tanks. Phase I: Missoula, Montana, SAIC Project No. 01-0833-08-3557-000. State of Montana.

Moore, A.C., R.L. Calderon, C.F. Craun, B.L. Herwaldt, A.K. Highsmith, and J.J. Juranek. 1994. Waterborne disease in the United States, 1991 and 1992. Journal of American Waterworks Association 86, no. 2: 87-99.

Nebraska Department of Environmental Control. 1977. Rules and regulations for the design, operation, and maintenance of septic tank systems in Nebraska. Lincoln, Nebraska: State of Nebraska, Title 124, Chapter 11, 1-2.

Nizeyimana, E., G.W. Peterson, M.C. Anderson, B.M. Evans, J.M. Hamlett, and G.M. Baumer. 1996. Statewide GIS/Census data assessment of nitrogen loadings from septic systems in Pennsylvania. Journal of Environmental Quality 25, March/ April: 346-354.

Robertson, W.D. 1994. Chemical fate and transport in a domestic septic system: Site description and attenuation of dichlorobenzene. Environmental Toxicology and Chemistry 13, no. 2: 193-191.

Robertson, W.D., and D.W. Blowes. 1995. Major ion and trace metal geochemistry of an acidic septic-system plume in silt. Ground Water 33, no. 2: 275-283.

Robertson, W.D., J.A. Cherry, and E.A. Sudicky. 1991. Groundwater contamination from two small septic systems on sand aquifers. Ground Water 29, no. 1: 82-92.

Roefer, P., S. Snyder, R.E. Zegers, D.J. Rexing, and J.L. Fronk. 2000. Endocrine disrupting chemicals in source water. Journal of American Waterworks Association 92, no. 8: 52-58.

Scandura, J.E., and M.D. Sobsey. 1997. Viral and bacterial contamination of groundwater from on-site sewage treatment systems. Water Science and Technology 35, no. 11-12: 141-146.

Seiler, R.L., S.D. Zaugg, J.M. Thomas, and D.L. Howcroft. 1999. Caffeine and pharmaceuticals as indicators of waste-water contamination in wells. Ground Water 37, no. 3: 405-410.

Shadford, C.B., D.M. Joy, H. Lee, H.R. Whiteley, and S. Zelin. 1997. Evaluation and use of biotracer to study ground water contamination by leaching bed systems. Journal of Contaminant Hydrology 28, no. 3: 227-246.

Shore, L.S., M. Gurevitz, and M. Shermesh.1993. Estrogen as an environmental pollutant. Bulletin of Environmental Contamination and Toxicology 51, no. 3: 361-366.

Tuthill, M.S., D.B. Meikle, and M.C.R. Alavanja. 1998. Coliform bacteria and nitrate contamination. Environmental Health 60, no. 8: 16-20.

U.S. EPA. 2001. Method 1601: Male specific $(\mathrm{F}+)$ and somatic coliphage in water by two-step enrichment procedure. U.S. Environmental Protection Agency, 821-R-010-30, April 2001. Washington, DC (http://www.epa.gov/nerlcwww/).

U.S. EPA. 2000. Current drinking water standards-national primary and secondary drinking water regulations. Office of Ground Water and Drinking Water. http//www.epa.gov/safewater/standards.html (accessed December 27, 2000).
Vengosh, A., K.G. Heumann, S. Juraske, and R. Kasher. 1994. Boron isotope application for tracing sources of contamination in groundwater. Environmental Science and Technology 28, no. 11: 1968-1974.

Verstraeten, I.M., R.L. Atkeson, and C.P. Stanton. 1998. Selected surface-water, ground-water, and tracer data from the Elkhorn and Platte Rivers and the alluvium near Ashland, eastern Nebraska, 1991-97: USGS Open-File Report 98-396.

Verstraeten, I.M., J.D. Carr, G.V. Steele, E.M. Thurman, M.T. Meyer, and D.F. Dormedy. 1999b. Surface-water/ground-water interaction: Herbicide transport into municipal collector wells. Journal of Environmental Quality 28, no. 5: 1396-1405.

Verstraeten, I.M., T. Heberer, J.R. Vogel, T. Speth, Z. Zuehlke, and U. Duennbier. 2003. Overview of occurrence of endocrinedisrupting and other wastewater compounds during water treatment with case studies from Lincoln, Nebraska (USA), and Berlin, Germany. In Endocrine Disrupting Compounds in the Environment, Practice Periodical of Hazardous, Toxic, and Radioactive Waste Management, ed. C. Adams and A. Bhandari. Vol. 7, no. 4: 253-263.

Verstraeten, I.M., Th. Heberer, and T. Scheytt. 2002a. Occurrence, transport, and fate of pesticides, pharmaceuticals, industrial products, and personal care products at river bank filtration sites. In Riverbank Filtration: Improving Source Water Quality, ed. C. Ray, G. Melin, and R.B. Linsky, 175-227. Dordrecht, The Netherlands: Kluwer Academic Publishers.

Verstraeten, I.M., M.J. Soenksen, G.B. Engel, and L.D. Miller. 1999a. Determining travel time and stream mixing using tracers and empirical equations. Journal of Environmental Quality 28, no. 5: 1387-1395.

Verstraeten, I.M., E.M. Thurman, E.C. Lee, and R.D. Smith. 2002b. Changes in concentrations of triazine and acetamide herbicides by bank filtration, ozonation, and chlorination in a public water supply. Journal of Hydrology 266, no. 3-4: 190-208.

Whitehead, J.H., and P.M. Geary. 2000. Geotechnical aspects of domestic on-site effluent management systems. Australian Journal of Earth Science 47, no. 1: 75-82.

Wilhelm, S.R., S.L. Schiff, and W.D. Robertson. 1996. Biochemical evolution of domestic wastewater in septic systems: 2. Application of conceptual model in sandy aquifers. Ground Water 34, no. 5: 853-864.

Wilhelm, S.R., S.L. Schiff, and W.D. Robertson. 1994. Chemical fate and transport in a domestic septic system: Unsaturated and saturated geochemistry. Environmental Toxicology and Chemistry 13, no. 2: 193-203.

Zaugg, S.D., S.G. Smith, M.P. Schroeder, L.B. Barber, and M.R. Burkhardt. 2002. Methods and analyses by the U.S. Geological Survey National Water Quality LaboratoryDetermination of wastewater compounds by polystyrenevinylbenzene solid phase extraction and capillary-column gas chromatography/mass spectrometry. Water Resources Investigation Report 01-4186. Denver: U.S. Geological Survey.

\section{Biographical Sketches}

Ingrid M. Verstraeten is a senior hydrologist with the U.S. Geological Survey International Water Resources Branch in Reston, Virginia. She is a licensed Professional Geologist and Professional Soil Scientist. She is an active member of scientific organizations, participated on scientific panels, convened special sessions at international meetings, and has been an associate editor and editor of scientific papers. Studies by Verstraeten have 
focused on monitoring programs; surface water/ground water interactions; transport and fate of herbicides, potential or known endocrine-disrupting compounds, and other emerging contaminants including pharmaceuticals; source-water protection; sensor technology; natural bank-filtration; and issues pertaining to chemical and physical drinking-water treatment. Verstraeten obtained her Doctoral Degree in Soil Science in 1994 and a Masters of Science Degree in Geochemistry in 1987 from the University of NebraskaLincoln. She obtained her Licenciate in the Geology Degree in 1979 and Candidate in the Sciences Degree in 1977 from the University of Leuven, Belgium. She may be reached at International Water Resources Branch, U.S. Geological Survey, MS 420 National Center, Reston,VA 20192; (703) 648-5689; imverstr@usgs.gov.

Gregory S. Fetterman currently serves as Congressional Liaison with the U.S. Citizenship and Immigration Service, Department of Homeland Security. Mr. Fetterman previously served as Coordinator of the LPRCA and as Assistant City Administrator for the City of Waukee, Iowa. He is completing a Ph.D. in Geography from the University of Nebraska-Lincoln, holds a Master of Public Administration from Drake University, and a B.A. in Political Science from Iowa State University. Mr. Fetterman's expertises include inter-governmental relations, public administration, community and regional planning, and natural resources management. He may be reached at 915 W. Burt Drive, Lincoln, NE 68521-3817; (402) 323-2465; two4cy@aol.com.

Michael T. Meyer has been a Research Geochemist with the U.S. Geological Survey (USGS) since 1988. He is currently head of the USGS, Kansas Water Science Center's Organic Geochemistry Research Laboratory. Dr. Meyer's research has focused on the development of analytical methods and the fate and geochemical transport of organic contaminants and their degradates in our nation's water resources. Dr. Meyer has conducted and collaborated on laboratory to national scale studies on the occurrence, geochemical transport, drinking, and waste water treatment of "emerging" organic contaminants such as new and understudied pesticides and pharmaceutical compounds in urban and agricultural settings. Dr. Meyer received his Ph.D. in Geology in 1994 from the University of Kansas. He can be reached at U.S. Geological Survey, 4821 Quail Crest Place, Lawrence, KS 66049; (785) 832-3544; mmeyer@usgs.gov.

Thomas D. Bullen has been a Research Hydrologist with the USGS since 1990. He currently supervises the Metal and SemiMetal Isotope Laboratory at the USGS in Menlo Park, California. Dr. Bullen's research has focused on the use of radiogenic and stable isotope systems such as strontium, boron, iron, calcium, chromium, and selenium to understand sources of and processes affecting dissolved constituents in natural waters. He is currently involved in several field studies at both pristine and anthropogenically impacted sites, both in the United States and abroad. Dr. Bullen received his Ph.D. in Geology in 1986 from the University of California at Santa Cruz. He can be reached at U.S. Geological Survey, MS 420, 345 Middlefield Road, Menlo Park, CA 94025; (650)329-4577; tdbullen@usgs.gov.

Sonja Sebree is a GIS Specialist with the U.S. Geological Survey, Water Resources Discipline in Lincoln. She has over ten years experience with GIS systems. She is an active member of the Nebraska GIS/LIS Organization, the Federal representative to the Nebraska GIS Steering Committee, has presented papers professionally at the ESRI International GIS Users Group in San Diego, California, and has been an associate author and author of scientific papers. Studies by Sebree have focused on ground water levels and surface water quality and quantity. Sebree is currently pursuing an M.A. degree in Geography from the University of Nebraska at Omaha. She obtained her B.S. degree in Geography from the University of Nebraska at Kearney in 1992. She can be reached at Nebraska Water Science Center, U.S. Geological Survey, 5231 S. 19th Street, Lincoln, NE 68512; (402) 328-4128; sksebree@usgs.gov. 